\title{
Analysing Opportunity for New Established Acne Focused Skincare Brand in Indonesian Beauty Industry
}

\author{
Lina Q. Herdyanti and Alvanov Z. Mansoor
}

\begin{abstract}
The skin is of utmost importance when people judge someone as beautiful. Maintaining skin health and people awareness toward their skin appearance is important. This beauty and health culture is validated in the presence of the growth of global skincare market from 2012 to 2025. More than 90 percent of world population is affected by acne at some point in their life. In 2010, acne ranked 8th in the list of most prevalent diseases in the world. Study from Indonesian Society of Dermatology and Venereology (INSDV) state that $60 \%$ Indonesian people are experiencing acne in 2006 and by 2008 the number reach $80 \%$ with sufferers ranging from 12-40 years old.

The idea of this research is to help business people find the business strategy as new entrant in the beauty industry. Research is intended to analyze the environment for new established acne focused skincare brand. This paper presents external analysis consist of Porter's Five Forces and Customer Analysis that will be concluded with Porter's Generic Competitive Strategy
\end{abstract}

Index Terms-Acne, Beauty Industry, External Analysis, Porter's Five Forces, Customer Analysis, Porter's Generic Competitive Strategy

\section{INTRODUCTION AND RESEARCH OBJECTIVES}

Many researchers and others have investigated what we humans identify as "beautiful" are symmetry, large evenly spaced eyes, white teeth, a well-proportioned nose and of course, a flawless complexion. The skin is of utmost importance when people judge someone as beautiful. There are 3,000 America women aged between 16-75 years old, the result reveals over $85 \%$ of the women were apply a minimum of 16 products both skincare and cosmetic a day to their face before they leave the house. ${ }^{[8]}$ The survey depicts the importance of maintaining skin health and people awareness toward their skin appearance. This beauty and health culture is validated in the presence of the growth of global skincare market from 2012 to 2025 . The graph shows a steady growth of worldwide market size in billion US dollars, all figures are Trefis estimates. This refers to the total sales of Skin Care products globally at the retail selling price or the price to the consumer.

Maintaining skin health means maintaining moisture, firmness, and skin complexion. One thing that is disturbing for appearance and health is the problem of acne. Acne is one of the most common disorders treated by dermatologists and other healthcare providers. More than 90 percent of world population is affected by acne at some point in their life. In 2010 , acne ranked 8th in the list of most prevalent diseases in the world, with a global prevalence of 645 million.

Published on April 26, 2020.

Lina Qonitah Herdyanti, Institut Teknologi Bandung, Indonesia. (e-mail: lina_qonitah@sbm-itb.ac.id).

Alvanoz Zpalanzani Mansoor, Institut Teknologi Bandung, Indonesia.

(e-mail: alvanov.mansoor@itb.ac.id)
Approximately 80 percent of people are affected by acne between onset of puberty and 30 years of age. In the US, the cost of acne in terms of treatment and loss of productivity is over 3 billion dollars per year. In 2011, over 19.24 percent of the population in the US was affected with acne. ${ }^{[3]}$

Study from Indonesian Society of Dermatology And Venereology (INSDV) state that $60 \%$ Indonesian people are experiencing acne in 2006 and by 2008 the number reach $80 \%$ with sufferers ranging from 12-40 years old. The majority of acne sufferers are teenagers at their 20 s with percentage of $64 \%$ and followed by $43 \%$ of adult at their $30 \mathrm{~s}$. The prevalence of acne in adult women is around $12 \%$ and in adult men $3 \%$. In another study found that acne is a skin problem through adolescence with a higher female prevalence than men in the age range of 20 years or more. ${ }^{8]}$ The peak age for acne is in the teens. Acne is not a fatal disease, but it is quite worrying because complaints that patients complain about are generally aesthetic complaints, so that if it occurs it will cause psychological torture for sufferers. Acne can have a negative impact on sufferers' quality of life, self-esteem, mood, increase anxiety, depression, and suicide ideas. ${ }^{[4]}$

This phenomenon becomes an opportunity to develop acne focused skincare line products aims to provide a variety of acne treatment options according to the needs of its users, from various types of acne and different skin types. The need for acne treatments is very diverse, while many on the counter products in Indonesia are still generalizing how to treat acne. Acne sufferers who do swamedication to deal with acne vulgaris tend to aggravate acne vulgaris due to the fact that most acne drugs in circulation contain keratolytic and abrasive materials and carriers that can close the skin pores so as to stimulate sebaceous gland activity. In view of this, the public is expected to carefully read the information contained on cosmetics labels or packaging, because there are 1.243 prohibited ingredients for use in cosmetics. ${ }^{[4]}$

\section{A. Statement of the Problem}

As a new brand that wants to compete in the Indonesian beauty market, the company wants to to expand opportunities to become a sustainable brand. Creating acne focused skincare line for various needs is challenging because of targeted segment is acne sufferers whose age range is quite wide which influence the consumer behavior and purchasing decision. Consumer behaviour does not remain the same or constant in every situation, it changes time to time. There are various factors which affects consumer behaviour. As the change comes in these factors, consumer behaviour also changes. The demographic factors which affect consumer behavior are: (1) age (2) sex (3) marital status (4) income (5) family background (6) education (7) occupation (8) family size (9) geographic factors (10) psychological factors. ${ }^{[7]}$ 


\section{B. Research Objectives}

This study aims to see how opportunities and threats for new established acne focused skincare companies who want to compete in the beauty industry. In addition, this study aims to determine customer preferences in choosing acne skincare products and what factors can influence the customer's decision to buy skincare products. As a new comer in Indonesian beauty industry there are a lot of to catch up. In this particular research, researcher wants to analyze the effect on acne sufferers' consumer behavior in purchasing decision, in order to determine the right strategy to build awareness towards newly established skincare brand. The researcher hopes the strategy will help the company minimize the failure in the future.

\section{RESEARCH METHODOLOGY}

In this research, researcher selected both quantitative and qualitative to get deeper understanding about consumer behaviour and acne skincare products purchasing channel. In order to get better possible result with validity of robust data from quantitative research and complete understanding of qualitative, both approach should be combined. [1]

The quantitative and qualitative approach are gathered respectively as sequential data gathering where a qualitative study is conducted as an explanatory to follow up findings on quantitative study as exploratory. Results from one method can be triangulated by using another method. ${ }^{[2]}$ For the quantitative approach, researcher conducted an analysis of questionnaire's result that had been distributed to prospective customer to gain some insights about the need of local acne focused skincare product. Researcher reinforced initial findings with qualitative approach by doing interview to the most potential targeted market age group to validate and map out customers' interest and perception towards acne focused skincare products.

\section{EXTERNAL ANALYSIS}

\section{A. Porter's 5 Forces}

Porter's Five Forces model is used to analyze the competitive environment of a business that can be used for strategy development in many industries. The model introduced in the article titled "How Competitive Power Shapes Strategy" has five basic forces that shape the structure of an industry and determine the competitive level of an industry. These forces are very influential on the long-term potential profitability and attractiveness of the company in the future. ${ }^{[6]}$ The result of Porter's Five Forces analysis can be seen in Figure 1.

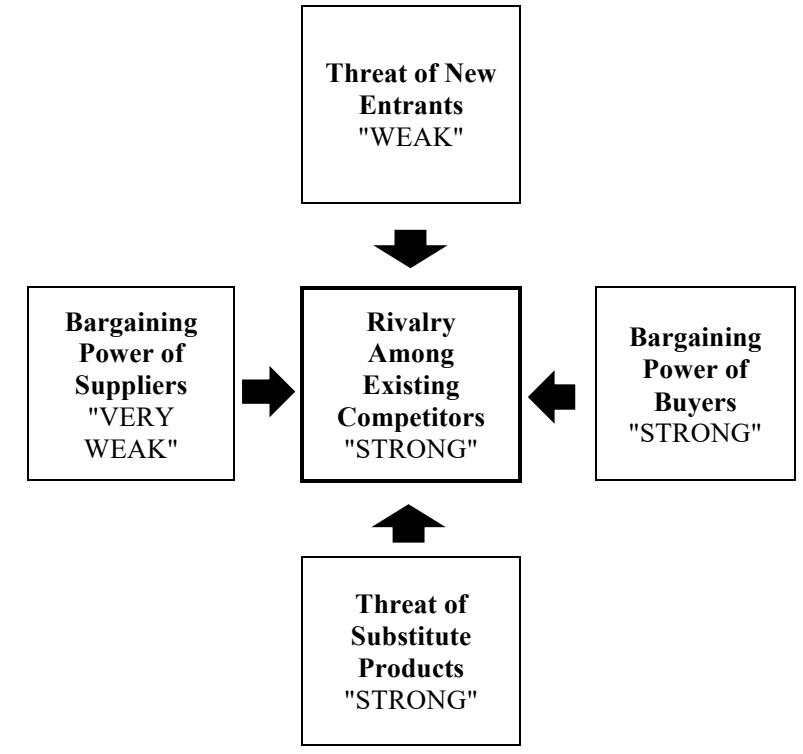

Figure 1: Porter Five Force Analysis Result

Rivalry among competitors, threat of buyers power and substitute product are in strong level. However, threat of new entrant and buyers suppliers power are weak and it can be utilized to create product's differentiation in order to strive in the industry. To conclude, the industry of beauty products in Indonesia still have good opportunity and profitability. The government is optimistic that the cosmetics industry will grow $9 \%$ in $2020 .{ }^{[5]} \mathrm{New}$ entrant in this industry needs to prepare the right business strategy and ready for continuous product's innovation.

\section{B. Customer Analysis}

Researcher conducted a potential customer survey towards 660 acne sufferer skincare user in this research as an initial phase to delve further into the potential market segmentation and find out their basic info of acne experience and their behaviour towards acne skincare product. In order to obtain higher possible validity that represents the company target market, the researcher had made several criteria for questionnaire's respondents: male and female; living in Indonesia; aged between 13-65 years old: experienced acne problem at least once.

The findings from this reasearch stated that female hold biggest proportion of total 660 respondents who experience acne problem with $90 \%$ share. Followed by $10 \%$ of Male acne sufferers. Younger segment (18-24 years old) holds biggest proportion of total respondents with $57 \%$ of share, whilst older segment (25-34 years old) is accounted with 38\% of share. This result depicts that Indonesian acne sufferers are motsly in late adolescent and early adulthood. In term of residential area, the researcher found out that East Java holds the highest percentage of total respondents with $53 \%$ of share, followed by DKI Jakarta, West Java, and Central Java. However, as this research was conducted through purposive random sampling methodology, the researcher could not conclude that East Java holds bigger market compared to any areas.

Respondents prefer to purchase per unit skincare product rather than set package skincare product. Respondents are using marketplace (47\%) prior to purchase acne skincare product and product's effectivity $(57 \%)$ is the most influential factor in their decision making process. More than $45 \%$ 
respondents are admitting that they are actively seek information online and more than $40 \%$ repondents are also asking for friends or family members' recommendation before purchase skincare products. However, there are a distinct findings of answers inconsistency between two age group where late adolescent prefer Youtube review more over word of mouth, in contrary more early adult are choosing word of mouth over Youtube with slightly different percentage.

As a further reasearch, the researcher conducted an in depth interview to potential target market to discover more about customer's perception, decision making process, and expectation towards local acne focused skincare products. The data collected from in depth interview are long explanation verbal answer from potential customers in each age group in the form of words. The interview are adressed to the main age group of acne sufferers, with each respondent chosen from each age group with the criteria: female; living in Java; aged between 18-34 years old; acne sufferers; and skincare user.

Through in depth interview, the researcher found that the majority of potential customers are prefer to purchase international brands as their daily skincare. They perceive that international brands have better technology to create skincare formulation. Some late adolescent interviewees stated that they do not able to afford imported products. Late adolescent interviewees are more aware and excited towards local skincare brand emergence rather than interviewees from early adulthood age group. Most of interviewed adolescent argued that local skincare brand need to improve their formulation quality and branding and they have tried many indie local brand, whereas older interviewees have tried less products from indie local brand. Most of the potential customers are excited with acne focused skincare line as long as it will be affordable.

Both potential customers from late adolescent and early adulthood age group are doing some research regarding product's review to help their purchasing decision. The most utilized media are Female Daily Network, Youtube, and Instagram. In terms of acne skincare products reference, most of the potential customers prefer honest review from noncelebrity figures as they believe that famous social media celebrities are paid to do the review. More adult interviewees are asking for friend's recommendation before purchase skincare products than teen interviewees that are more confidence with their purchasing decision only by doing independent research. Product's primary uses, price, and ingredients used are top consideration in their decision making.

Direct advertising is not really trigger customers' purchase intention, instead they are usually persuaded by other people's review that they find. Most of potential customers from both age group tell their friends and relatives about their skincare usage experience, but adolescent interviewees are more active in sharing their experience online. They are expect well designed packaging, lightweight formulation, complete basic skincare, halal licenced, and BPOM certified from local skincare brand. Half of the interviewed potential customers are willing to wait 1-2 months to see product's efficacy. In addition, more interviewees from adulthood age group are willing to wait until 3-4 months.
Potential customers are willing to spend IDR 70.000200.000 for local acne focused skincare products. Interviewees are also excited if local skincare brand are having offline store so that they can experience the formulation's texture and do skin consultation. Official brand's offline store, marketplace, and drugstore are the place where customers shop the most of their skincare products. Some of adult potential customers alson mentiones beauty clinic, mall retail store, and Instagram online shop as their shopping channel. Instagram, Sociolla Web Journal, and Youtube are the most utilized media to get latest skincare information.

Most potential customers expect local acne focused skincare brand to provide educational content about skin. Younger interviewees prefer to receive brand's update from e-mail subscription. In contrary, older interviewees do not like the idea of getting many update via e-mail. The majority of interviewees are liking discount, buy 1 get 1 , and free sample in every purchase as way of brand's promotion. Most of interviewees prefer environmental friendly and safety packaging such as reusable pouch, cardboard box, and shredded paper.

The researcher summarize the findings of major difference in terms of consumer behaviour that is influenced by age group or life cycle factor based on The Five Stage Decision Making Model by Silverman (2001) as consumer behaviour is inevitably be the basis for understanding decision process.

Table 1: Respondent Response to Skincare Local Brands

\begin{tabular}{|c|c|c|}
\hline Category & $\begin{array}{l}\text { Late Adolescent } \\
\text { (18-24 years old) }\end{array}$ & $\begin{array}{l}\text { Early Adulthood } \\
\text { (25-34 years old) }\end{array}$ \\
\hline Problem Recognition & $\begin{array}{l}\text { Excited towards } \\
\text { towards local acne } \\
\text { focused skincare } \\
\text { brand. } \\
\text { Perceive that local } \\
\text { brand's growth is } \\
\text { good but need } \\
\text { improvement. } \\
\text { Use skincare as way } \\
\text { to fulfill skin needs } \\
\text { Cannot afford } \\
\text { expensive } \\
\text { international brand. } \\
\text { Have tried many } \\
\text { indie local brand, } \\
\text { namely For Skin } \\
\text { Sake, Avoskin, }\end{array}$ & $\begin{array}{l}\text { Not following the } \\
\text { update of local } \\
\text { skincare brand } \\
\text { emergence, but eager } \\
\text { to try local acne } \\
\text { focused skincare } \\
\text { brand. } \\
\text { Perceive local brand } \\
\text { is not better than } \\
\text { international brand. } \\
\text { Use skincare as } \\
\text { selfcare } \\
\text { Can afford higher } \\
\text { price skincare } \\
\text { Have tried less indie } \\
\text { local brand, but more } \\
\text { legacy brand, namely } \\
\text { Wardah, Viva, } \\
\text { Martha Tilaar. }\end{array}$ \\
\hline Info Search & $\begin{array}{l}\text { Digital media, } \\
\text { mainly Youtube is } \\
\text { highly used to seek } \\
\text { for product review } \\
\text { information. } \\
\text { Social media is } \\
\text { highy utilized as its } \\
\text { fast information } \\
\text { distribution on what } \\
\text { is currently trending. } \\
\text { Instagram is the most } \\
\text { preffered channel. } \\
\text { Eager to receive } \\
\text { brand's update via e- } \\
\text { mail. }\end{array}$ & $\begin{array}{l}\text { Friend's } \\
\text { recommendation is } \\
\text { more utilized in } \\
\text { searching for } \\
\text { skincare review. } \\
\text { Online community } \\
\text { platform is highly } \\
\text { utilized to discuss } \\
\text { and search for } \\
\text { skincare update, } \\
\text { mainly Female Daily } \\
\text { Network. } \\
\text { Prefer see brand's } \\
\text { update from brand's } \\
\text { platform. }\end{array}$ \\
\hline Evaluation & More confidence in & Asking other's \\
\hline
\end{tabular}




\begin{tabular}{|c|c|c|}
\hline & $\begin{array}{l}\text { their info search's } \\
\text { result. } \\
\text { Have more variable } \\
\text { figure as skincare } \\
\text { role model }\end{array}$ & $\begin{array}{l}\text { opinion to help their } \\
\text { purchasing decision. } \\
\text { Have less figure as } \\
\text { skincare role model }\end{array}$ \\
\hline Purchase Decision & $\begin{array}{l}\text { Marketplace holds } \\
\text { highest preffered } \\
\text { channel for purchase } \\
\text { skincare product } \\
\text { Offline channel is } \\
\text { still used due to its } \\
\text { complete shopping } \\
\text { experience and } \\
\text { beauty advisor } \\
\text { facility }\end{array}$ & $\begin{array}{l}\text { Marketplace and } \\
\text { offline channel are } \\
\text { also highly utilized } \\
\text { but there are more } \\
\text { options for } \\
\text { purchasing skincare } \\
\text { product like beauty } \\
\text { clinic and mall retail } \\
\text { (SOGO, Metro). }\end{array}$ \\
\hline Post Purchase & $\begin{array}{l}\text { Actively share } \\
\text { skincare usage } \\
\text { experience through } \\
\text { social media. } \\
\text { Willing to wait } 1-2 \\
\text { months to see } \\
\text { product's result. }\end{array}$ & $\begin{array}{l}\text { Actively share } \\
\text { skincare usage } \\
\text { experience from } \\
\text { mouth to mouth. } \\
\text { Willing to wait 3-4 } \\
\text { months to see } \\
\text { product's result. }\end{array}$ \\
\hline
\end{tabular}

\section{Porter's Generic COMPETItive StRategy}

According to Porter (1985), the relative position of a company in its industry will determine whether the company's profitability is above or below the industry average. Sustainable competitive advantage is the fundamental basis of long-term average profitability. Porter suggested four "generic" business strategies that can be adopted in order to obtain competitive advantage. Strategy deals with the extent of the scope of business activity is narrow versus broad, and the extent to which a business is willing to try to differentiate its products. There are two overall business strategies that could be followed by a company in order to gain competitive advantage, differentiation and low cost. Further, the two basic types are combined with the scope of activities lead to three generic strategies that can address a company to get higher performance in an industry, cost leadership, differentiation, and focus. In the focus strategy, there are two variants of cost focus and differentiation focus. Porter's Generic Strategies can be seen in the figure below.

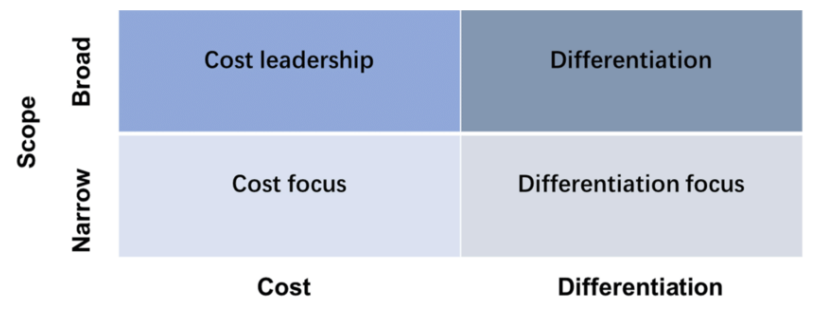

Source of Competitive Advantage

Figure 2: Porter's Generic Strategies

In the long run, a skincare company needs to determine its suistainable competitive advantage by offering customers greater value that can be achieved by provide lower prices or greater benefits. Determine in which quadrant the brand can define the overall business strategy, it is important to use Porter's Five Forces analysis to understand the nature of beauty industry. Threat from the Porter's Five Forces analysis are buyers power, the threat of substitution, and competitive rivalry (See Figure 1). In order to address the threats, a new established skincare brand needs to offer distinctive product that are different from the competition, with customers valuing the differentiation. Thus, it can reduce the buyers power, eliminate the threat of substitution, and might come out on top of competitive rivalry. The suitable strategy for acne focused skincare brand is in the differentiation strategy. The distinctive aspects can be implemented to both product and service offered,

\section{CONCLUSION}

The beauty industry, especially skincare products, has been growing overtime. The emergence of new indie local skincare brand are noticeable and very high in demand by Indonesian women. The government is optimistic that the cosmetics industry will grow $9 \%$ in 2020 . In terms of acne skincare product, the majority of Indonesian people are experiencing acne with the peak of acne autbreaks at adolescent age group, thus it provides opportunities for business people who want to develop acne focused skincare brand. This momentum is an opportunity for entrepreneurs in skincare industry to develop, since the size of market size is promising.

The condition of industry of beauty products in Indonesia still have good opportunity and profitability. New entrant in this industry needs to prepare the right business strategy and ready for continuous product's innovation. Rivalry among competitors, threat of buyers power and substitute product are in strong level. However, threat of new entrant and buyers suppliers power are weak and it can be utilized to create product's differentiation in order to strive in the industry.

Indonesian customer already have a great respond towards local skincare products despite any customers who prefer international skincare brands. Whereas, there are major difference in terms of consumer behaviour that is influenced by age group or life cycle factor (See Table 1). In order to capture the market, new entrant in this industry should formulate effective and efficient business strategy as acne commonly outbreak in two different stage, adolescent and adulthood.

Acne sufferers purchasing decision are mainly influenced by product's quality, benefit, efficacy, ingredients, price and legality. The most important factor for customers in choosing skincare products is product's benefit or primary uses. Customers are willing to pay more if the product's benefit fit their needs. Another important aspect to consider is the price and ingredients. Customers tend to choose more affordable product with the sampe benefit and ingredients. The conclusion is that benefit, price, and ingredients are the main factors for customers, as a result these three factors are priorities for acne skincare company to develop their products' differentiation.

In order to capture the market, a skincare company should increase the awareness of potential customers towards their newly launched product. In Indonesia, digital media is highly utilized by the society to search for skincare product review as its fast information distribution on what is currently trending, mainly Youtube and Instagram. However, for adult acne sufferers online community platform is highly utilized to discuss and search for skincare update as they can have interactions to share their experience. Marketplace holds highest preffered channel for purchase skincare product but offline channel is still used due to its complete shopping 
experience and beauty advisor facility.

\section{REFERENCES}

[1] Bryman, A. and Bell, E. (2013). Business Research Methods. Oxfors University Press, Oxford.

[2] Creswell, J. W. (2003). Research Design Qualitative, Quantitative and Mixed Methods Approaches Second Edition. New Delhi: Sage Publications.

[3] Effemarket. (2017). Global Acne Report 2016-2027.

[4] Graham, B. and Burns, T. (2005). Acne Vulgaris. Dalam: Graham, B. Brown. Burns, ed. Lecture Notes Dermatologi. Jakarta: Erlangga.

[5] Ministry of Industry of the Republic of Indonesia (2018). Lifestyle Changes Push the Cosmetics Industry

[6] Porter, M. (2008). The Five Competitive Forces That Shape Strategy. Harvard Business Review

[7] Rakesh. (2014). Impact of Demographic Factors on Consumer Behaviour: A Consumer Behaviour Survey in Himachal Pradesh.

[8] Skinstore. (2017). Women's Face Worth. https://www.skinstore.com/blog/skincare/womens-face-worth-survey$2017 /$

[9] Sudharmono A. (2009). Laser Skin Resurfacing. Seminar Perspective of Laser Dermatology. Surabaya.

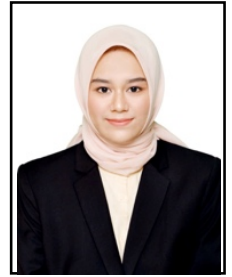

Lina Q. Herdyanti was born on August 24, 1995 in Surabaya, Indonesia. She graduated from Sepuluh Nopember Institute of Technology in 2016 majoring in design. She continued her postgraduate in Masters of Business Administration at the Bandung Institute of Technology, Indonesia, and graduated in 2020. Lina Qonitah Herdyanti is currently an entrepreneur in the skincare industry and actively join projects in creative industries.

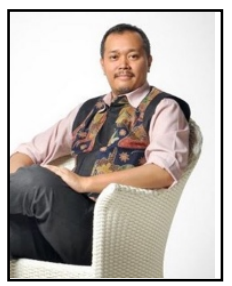

Alvanov Z. Mansoor was born in November 27, 1974 in Bandung, Indonesia. He completed his doctoral program in Institut Teknologi Bandung majoring in Art and Design studies in 2012 after graduated from Master of Management program, Telkom University in 2005. His exeprtise in research are cultural studies, media studies, visual storytelling, and creative business. Dr. Mansoor, is currently works as lecturer, researcher, boardgame designer, and creative business and visual storytelling consultant. Dr. Mansoor is eager to contribute in cross and multidiscipline studies and various creative projects. 